\title{
Los derechos humanos en las resoluciones de los centros de operaciones de emergencias cantonales. Caso: Babahoyo
}

Human rights in the resolutions of cantonal emergency operations centres. Case: Babahoyo

Alexandra Dolores Molina-Manzo

ub.alexandramolina@uniandes.edu.ec

Universidad Regional Autónoma de los Andes, Babahoyo

Ecuador

https://orcid.org/0000-0002-4778-512X

Beatriz Barrionuevo-Intriago

db.beatrizvbi61@uniandes.edu.ec

Universidad Regional Autónoma de los Andes, Babahoyo

Ecuador

https://orcid.org/0000-0003-2304-5554

Luis Cherres-Arana

db.luisaca93@uniandes.edu.ec

Universidad Regional Autónoma de los Andes, Babahoyo

Ecuador

https://orcid.org/0000-0002-7513-1836

Damary Delgado-Henríquez

db.damaryvdh41@uniandes.edu.ec

Universidad Regional Autónoma de los Andes, Babahoyo

Ecuador

https://orcid.org/0000-0001-5877-9844

Recepción: 15 de septiembre 2021

Revisado: 25 octubre 2021

Aprobación: 15 de noviembre 2021

Publicación: 01 de diciembre 2021 


\section{Estimado Editor (a):}

El mundo está viviendo una pandemia, causada por un virus denominado COVID 19, mismo que generó una emergencia sanitaria casi en la totalidad de países del mundo y en Ecuador no fue diferente, es así que el Diario El Comercio (2020) en su edición del 11 de marzo del 2020, titulaba "Gobierno decreta emergencia Sanitaria en Ecuador por COVID - 19" es así que en este diario se resumía lo que el presidente de la República había manifestado en una cadena nacional previa, que entre otras eran varias acciones para evitar la rápida propagación del virus.

Por otra parte, el Ejecutivo emitía el Decreto Presidencial 1017 (Ecuador. Presidencia de la República, 2020) del 17 de marzo del 2020, con el cual el país se declaraba en estado de excepción, como lo establece lo siguiente:

Artículo 1. DECLÁRESE el Estado de excepción por calamidad pública en todo el territorio nacional, por los casos de coronavirus confirmados y la declaratoria de pandemia de COVID 19 por parte de la Organización Mundial de la Salud

Artículo. 3 SUSPENDER el ejercicio del derecho a la libertad de tránsito y el derecho a la libertad de asociación y reunión (......), y los comités de operaciones de Emergencias del nivel desconcentrados se activarán y coordinarán con las instituciones pertinentes los medios idóneos de ejecución de estas suspensiones.

Esto significaba que los COE de los GAD se activaban, con esta delegación realizada por el Ejecutivo vía decreto, los COE iniciaron sus operaciones para enfrentar al COVID 19 y emitieron varias resoluciones durante y posterior al estado de excepción, misma que han afectado de manera positiva o negativa a los derechos de los ecuatorianos consagrados en la Constitución de la República. Ya en el marco específico de la ciudad de Babahoyo, se aplicaron las recomendaciones del COE Nacional en algunos casos, en otros casos y en gozo de la Autonomía que tienen los GADs medidas un poco extrañas y que podrían encontrarse en alejadas de un ordenamiento jurídico o una capacidad técnica y operativa para dar seguimiento a lo resuelto por ellos. 
Según el Reglamento de la Ley de Seguridad Pública y del Estado (2014) los Comités de Operaciones de Emergencias (COE) son instancias interinstitucionales responsables en su territorio de coordinar las acciones tendientes a la reducción de riesgos, y a la respuesta y recuperación en situaciones de emergencia y desastre. Esto quiere decir que, en el COE, participan representantes de varias instituciones que acuerdan en determinado momento trabajar por un fin común, como por ejemplo GAD, Empresas públicas creadas por el GAD, fuerzas militares y policiales, direcciones Distritales, cada uno dentro de su competencia. Al respecto, Echeverria (2018):

Procesos administrativos. - No existe un proceso administrativo claro y definido para la formulación de las actividades que debe cumplir el COE. Al no existir líneas de actuación claras, que permitan una adecuada atención de la emergencia o desastre, existe una falta de coordinación en la respuesta. Independiente de la naturaleza del evento adverso, en las operaciones de emergencia, la logística para el establecimiento de los COE es requerida para apoyar a las organizaciones e implementación de acciones de respuesta, para que estas no solo sean rápidas, sino también ágiles y efectivas.

Así mismo, Ecuador mantiene ratificados varios convenios en materia laboral como por ejemplo La Declaración Universal de los Derechos Humanos emitida por la Organización de las Naciones Unidas (ONU); las Naciones Unidas; 3ra Edición; Nueva York, (1969 pág. 653), como se especifica:

Artículo. 23.Toda persona tiene derecho al trabajo, a la libre elección de su trabajo, a condiciones equitativas y satisfactorias de trabajo y a la protección contra el desempleo... Toda persona que trabaja tiene derecho a una remuneración equitativa y satisfactoria, que le asegure, así como a toda su familia una existencia conforme a la dignidad humana y que será completada, en caso necesario, por cualquier otro medio de protección social.

Los COE iniciaron sus operaciones para enfrentar al COVID 19 y emitieron varias resoluciones, que han afectado de manera positiva o negativa a los derechos de los ecuatorianos consagrados en la Constitución de la República. Pero al momento de emitir una resolución participan representantes de varias instituciones que acuerdan en determinado momento trabajar por un fin común, como por ejemplo GAD, Empresas públicas creadas por el GAD, fuerzas militares y policiales, direcciones 
Distritales, cada uno dentro de su competencia y es así como existen las resoluciones, pero no se cumplen a cabalidad entonces que tan eficiente es regular diversos derechos de los ciudadanos si no van a ser cumplidos sin embargo limitan al derecho al trabajo de los propietarios y empleados de bares y discotecas, produciéndose así un conflicto de derechos.

\section{FINANCIAMIENTO}

No monetario.

\section{AGRADECIMIENTO}

A la Universidad Regional Autónoma de los Andes, Babahoyo, por motivar el desarrollo de la Investigación.

\section{REFERENCIAS CONSULTADAS}

Asamblea Nacional Constituyente de la República del Ecuador, (2008). Constitución de la República del Ecuador. [Constitution of the Republic of Ecuador]. Montecristi. Registro Oficial 449 de 20-oct-2008. Recuperado de https://n9.cl/sia

Asamblea Nacional. (2014). Ley de Seguridad Pública y del Estado. [Law on Public and State Security].Registro Oficial Suplemento $N^{\circ}$. 35.REcuperado de: https://n9.cl/1v732

Diario El Comercio. (2020). Gobierno decreta emergencia sanitaria en Ecuador por covid-19. [ Government decrees health emergency in Ecuador due to covid-19] Recuperado de: https://n9.cl/miojc

Echeverria, V. O. (2018). Análisis comparativo de los procesos de gestión del Comité de Operaciones de Emergencia y del Sistema Integrado de Seguridad ECU 9-11. [Comparative analysis of the management processes of the Emergency Operations Committee and the Integrated Security System ECU 9-1-1]. Tesis de maestría. Universidad Andina Simón Bolívar, Ecuador.

Organización de las Naciones Unidas (1969). Declaración Universal de los Derechos Humanos. [Universal Declaration of Human Rights]. Nueva York: Naciones Unidas. Recuperado de: https://n9.cl/imy5 
FUNDACIÓN KOINONIA (F.K). Santa Ana de Coro, Venezuela

Alexandra Dolores Molina-Manzo; Beatriz Barrionuevo-Intriago; Luis Cherres-Arana;

Damary Delgado-Henríquez Presidencia de la República. (2020). Decreto Ejecutivo №. 1017. [Executive Decree
No. 1017]. Quito. Recuperado de: https://n9.cl/xx68

(C2021 por los autores. Este artículo es de acceso abierto y distribuido según los términos y condiciones de la licencia Creative Commons Atribución-NoComercial-Compartirlgual 4.0 Internacional (CC BY-NC-SA 4.0) (https://creativecommons.org/licenses/by-nc-sa/4.0/). 